\section{ECONOMICS}

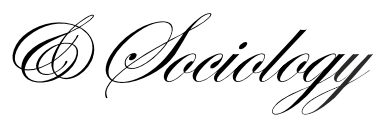

\title{
CHILDREN OF THE STREET: WHY ARE THEY IN THE STREET? HOW DO THEY LIVE?
}

Jérôme Ballet,

University of Bordeaux,

GREThA, France,

E-mail:jballetfr@yahoo.fr

Received: September, 2015

1st Revision: October, 2015

Accepted: December, 2015

DOI: $10.14254 / 2071-$

789X.2015/8-4/10

\begin{abstract}
Children form one of the main populations to be victims of poverty worldwide. Children of the street are now regarded as a particularly vulnerable population. This article tackles two questions: firstly, the question of which factors can be decisive in the phenomenon of children of the street. It opens a debate on the respective roles of poverty and of other factors, such as domestic violence and parental neglect. Secondly, it considers the question of how they live in the street. Children develop survival strategies that are obviously based on their activities, but also involve an organization that calls for analysis in terms of strategic positioning on the territory they occupy.
\end{abstract}

JEL Classification: J13, J24, $\mathrm{J} 81$

Keywords: Children of the street, poverty, child labor, child abuse and neglect, gang, violence.

\section{Introduction}

Children form one of the main populations to be victims of poverty worldwide (Gordon et al., 2003). Children of the street are now regarded as a particularly vulnerable population (see for instance UNICEF, 2002; Wernham, 2001). International agencies and NGOs have already explored central issues regarding these children (e.g. UNICEF, 2002; CIDA, 2001; Witter, 2002).

All children of the street are subject to some form of institutional violence, which denies them the right to live and to develop fully in a secure environment. Even where there is some justification for the prevailing public opinion, attempts to eradicate the problem by violence are clearly short-sighted and poorly thought out. This aggressive approach mirrors extensive misunderstanding about the living conditions and difficulties faced by these children and is, in part, fueled by the media seeking to sensationalize the issue. For example, regular allegations are made that things such as drug-related crime and poor mental health are rife amongst children of the street, none of which is supported by any empirical evidence (Aptekar and Stocklin, 1996). In fact, children of the street usually actually adopt socially constructive strategies (Orme and Seipel, 2007).

Children of the street face many difficulties. They are marginalized by their societies and are seen as pariahs. In countries in Africa and Latin America, businessmen hire police to get rid of children of the street as they are considered to be a threat to business (Aptekar and Stocklin, 1996). In Latin America, the issue is compounded by class and race. An elite class 
with European origins produces no children of the street. Children of the street come either from the indigenous peoples or have African origins (Aptekar, 1994). Claims that the problem stems from poor or inadequate parenting may be made simply to justify police attacks on the basis of an attempt to instill respect for authority. In fact, it is more likely to polarize both the problems and the societies in which they are found.

With the goal to correct the sensationalist view on children of the street, this article provides an overview on two questions: why children live in the street; how they live.

The article is constructed as follows: in the first section we look at the definition and extent of the phenomenon. In the second section, we review the factors that directly promote the phenomenon. These factors are mainly of two types: poverty and neglect or violence within the family. From this standpoint it appears that a more detailed analysis of the interactions between these two categories has yet to be carried out. In the third section, we describe how children of the street survive. This mainly involves their organization into gangs on the territory they occupy. Finally, we conclude.

\section{The definition of children of the street and issues related to measurement}

Throughout the substantial literature, terms such as street "children" and "youth" are used extensively. The expression "street children" is far from being an accurately defined category. Hall and Montgomerry (2000) state that these terms are not neutral, and are used as much to alert the public to the living conditions of such individuals as to describe their stages of life. However, the lack of precision of the term also makes it difficult to determine the exact extent of the problem.

\subsection{Street children: distinguishing between children on the street, children at risk and children of the street}

According to UNICEF (1984), street children constitute a multifaceted phenomenon that can be divided into at least three categories: children on the street, children at risk, and children of the street. According to Lalor (1999), the category of children on the streets is made up of children working on the streets in order to survive. These children generally belong to a family, return home at night (Le Roux, 1996), and are under their parents' protection. It is household poverty that pushes these children onto the street. For instance, children on the street contribute up to $30 \%$ of household income (Rizzini and Lusk, 1995; ILO, 1996). This is the largest category of street children. The category of children at risk includes the urban poor who form a reservoir of street children. The last category, that of children of the street, is a multifaceted one, comprising several subcategories: abandoned, orphaned, and runaway children. Densley and Joss (2000) state that children of the streets regard the street as their home: it is the place where they live, where they work and develop bonds with other children of the streets. They view their family ties in a negative light.

These three categories are closely linked. The category of children on the street feeds into that of children at risk, which itself feeds into that of children of the street.

This categorization has sometimes been rejected in favor of others (see for instance Felsman, 1984; Cosgrove, 1990; Lusk, 1992), but these alternative categorizations quite often prove to be ad hoc and non-analytical (Glauser, 1990; Panter-Brick, 2000). Most analyses actually use distinctions that correspond to those proposed by UNICEF, even if the names of categories are often markedly different (see among others Ennew, 1994; Barker and Knaul, 1991; Consortium for Street Children, 1998; Raffaelli, 1999).

According to Lalor (1999), these distinctions shed light on the reasons that drive children to migrate onto the streets. Furthermore, Panter-Brick (2003) considers that 
classifying these children is useful as long as the categories are not perceived as discrete and homogeneous. The use of the term "street children" certainly poses problems, but few alternatives are available - apart from local terms - to refer to this particular group of children (Ennew, 2000; Panter-Brick, 2003).

\subsection{The difficulty of assessing the number of children of the street}

Estimating the number of children of the street is very difficult for several reasons. Firstly, very broad estimations are used by international agencies (UNICEF mainly) to draw the attention of the general public and political decision-makers to their work. The calculations provided to demonstrate phenomenon are symbolic rather than the product of exact estimation (Ennew, 2000). Secondly, children on the street are also potentially "children at risk", and they can fall into the category of children of the street at any time. Children at risk who are on the street still have some irregular contact with their parents. They can return home when they want to. Thus, the way children can move "in" and "out" of the street makes it difficult to assess this category of children (See Gurgel et al., 2004, for a discussion and illustration on Brazil). As long as the child remains within the household and works on street s/he is counted as child labor. Kombarakaran (2004) shows that in India, 43\% of children of the children of the street have been on the street for approximately 3-4 years, and $42 \%$ of these children have spent between 5 and 9 years on the street. Just $15 \%$ of children of the street are "new comers". Thirdly, it is not easy to assess the phenomenon accurately insofar as children of the street are mobile, and move from one area to another in search of better survival opportunities, or because of public assaults (police, city people etc.) (see, among others, Young, 2004, for an illustration in Uganda; Morelle, 2006, on Cameroon).

As a matter of fact, some studies of street children conducted in Latin America (Rizzini and Lust, 1995), but also in Africa (Aderinto, 2000), reveal that the phenomenon of children of the streets is quite marginal, representing only $1 / 10^{\text {th }}$ of the total number of street children, whereas Densley and Joss (2000) state that they make up 20\% of the total. However, even if only one tenth of street children live on the street permanently, as a minority they continue to constitute a considerable social challenge throughout the world.

\section{The poverty hypothesis}

\subsection{The hypothesis that poverty is the explanatory factor, and the confusion of different categories}

As mentioned previously, the appellation "street children" encompasses quite a varied set of situations, the main feature of which is the link with the street. This common terminology has created some confusion in explaining apparently very similar phenomena. As far as children on the street are concerned, a tendency has emerged which regards the "economic poverty" hypothesis as the main explanatory factor. Such a tendency has developed all the more easily since children on the streets represent the vast majority of street children (Ebigbo, 2003; Taçon, 1992). The economic argument concerning children on the streets has thus been applied to the whole population of street children, establishing itself as the main explanation of the phenomenon (e.g. Olley, 2006; Aderinto, 2000; Alexandrescu, 1996; Rizzini and Lusk, 1995; Peacock, 1994). Children of the streets are then equated with children on the streets, and the other categories are not taken into account properly.

The role of economic poverty has been discussed on numerous occasions. Blanc (1994) stresses, for example, that although "material poverty" (material poverty is defined as income poverty) encourages the phenomenon of street-working children, they do not all 
become street-living children for all that. However, the interactions between these categories suggest that, without providing a complete explanation, poverty could well influence children's vulnerability to become children of the street. In other words, poverty feeds into the category of children at risk, some of whom will go on to become children of the street.

Understanding what underlies the transition from one category to the other is therefore a major requirement for effective public intervention. Two main explanations are usually given (Aptekar, 1994): the hypothesis of poverty and that of aberrant families. These two hypotheses explain why children decide to leave the family home. We should note from the outset that unlike the definition of children of the street (see the first section), this category leaves out abandoned and orphaned children. Ignoring these two sub-categories of children does however cause some problems as they also feed into the children of the streets, and by definition form part of this category. What it sets out to do is to find out why children decide to leave their family of their own volition. By definition, children who have been abandoned and orphans do not have any such choice.

\subsection{The poverty hypothesis once again}

Children migrate onto the streets on their own initiative as a result of their unsatisfactory living conditions at home (Felsman, 1989; Lucchini, 1996). For instance, a study conducted in Nigeria insists on the fact that children deliberately leave their homes to earn a living when their parents are unable to feed them in a decent manner (Aderinto, 2000). Hunger then becomes a reason for leaving home. Leaving the household becomes a rational decision that children take to ensure their well-being. According to Aptekar (1988), in Colombia $48 \%$ of street children left their homes for financial reasons. Many other studies have confirmed the role of economic poverty in the phenomenon of the migration of children onto the streets (for instance and among others, Olley, 2006, on Nigeria; Hecht, 1998, on Brazil; Alexandrescu, 1996, on Rumania; Rizzini and Lusk, 1995, on Latin America; Peacock, 1994, on Africa).

Poverty is a decisive factor, but children of the street are also very likely to come from big households. In Aracaju, Brazil, the average size of a household is six family members. This means that when a household is facing poverty, some children take the decision to work to bring in money. As the child begins to earn, particularly on the street, elements of that lifestyle become cumulative and coupled with the child's feelings that s/he does not want to be a burden on the family, step by step the child takes the decision to leave the family home to settle in the street. Their decision to abandon their household is a rational one taken both to preserve household harmony, and also to allow the child to be more independent, to live his or her own life (Aptekar, 1989a). These children of the street have not completely broken off all contact with their households; they often send money to their parents (Aptekar and Stoplin, 1996), and return home to visit their parents, albeit irregularly. The difficulty is that the longer they stay on the street and adopt a lifestyle that commonly includes becoming addicted to drugs, the harder it becomes to earn the money they need to support themselves. This adds to their feelings of shame, so that any return home becomes less likely, and eventually the streets become their permanent home.

De Boeck (1999) for instance, points out in the case of the Democratic Republic of Congo, the phenomenon of the massive migration of teenagers into the Angolan province of Lunda Norte seeking wealth from the manna of diamonds. Some of them do indeed return with considerable economic power, and this results in an unprecedented generation divide; some of these teenagers return with far more money than their parents. Others, who have been less lucky, end up in the street. 
Meanwhile, poverty alone is not enough to explain the phenomenon of children of the street, and many studies have pointed out that neglect and abuse of children also need to be taken into account. For instance, Aptekar (1989b) points out that in the case of Colombia although a not insignificant proportion of children run away from the family home for financial reasons (48\%), others migrate onto the streets as a result of domestic violence.

\subsection{Abuse and neglect}

In the opinion of Lalor (1999), the main factor that drives children to leave their home is child abuse and neglect, following family disintegration, the parents' separation or divorce, the death of a parent, or remarriage (see also Martins, 1996; Swart-Kruger and Donald, 1996; Bibas, 1998). After the remarriage of a parent, children are frequently abused and forced to leave the house by the stepfather or mother. By abuse we mean rows, underfeeding, overwork, nagging and physical beating.

According to a study conducted in Egypt by UNICEF (2000) in the cities of Cairo and Alexandria, $62 \%$ of the children interviewed said they had left their family home because of parental neglect, lack of supervision and affection. $82 \%$ of these children also said that the immediate reason for their being on the streets was child abuse whether by family or at work. They were forced to leave home because they were not accepted by their family, particularly in the case of non-biological children.

Single-parent families are therefore more likely to produce children of the street, particularly if these families are also poor. In Acaruja, Brazil, 46\% of the households are headed by a single female (with only $7 \%$ headed by a single male) (Abdelgalil et al., 2004). In many cases families are broken up as a result of events such as death (HIV/AIDS), separation or divorce (Matchilda, 1999; Lalor, 1999; Aderinto, 2000) and by war (Veal and Dona, 2003). Children from these households are often seen as having some connection with street life, because the single surviving parent has no time for childcare. Logically, children who spend a lot of time on the street, and who become familiar with the vagaries of street life, can become attracted to it as a way of life. The pattern becomes progressive, as adults who have been working since their early childhood appear to accept that their children may in turn take to the street (Abdelgalil et al., 2004). This lack of care can have emotional and psychological effects, facilitating running away from home (Oliviera Ribeiro and Trench Ciampone, 2001).

Belonging to a one-parent family makes children more vulnerable, and likely to become children of the street, but in contrast, some studies reveal that some children of the street come from families with two parents. Ballet (2006) highlights, for example, in the case of Mauritania, that the children of the street come from united families (two parents) as often as from one-parent families. In both cases, the parents are away from home for most of the time, and the children are neglected. Worse still, in some cases, the children are chained up while the parents are away to stop them running away. Obviously, as soon as their chains are removed, these children run away from home.

Some cultural practices also increase the risk of abuse and neglect. For instance, in sub-Saharan societies, the adults, especially the fathers, exercise all the power (political, domestic and financial). The eldest son has to wait until his father's death to enjoy any advantages. In these societies, the relationship between children (juveniles) and adults is a factor that drives children to run away from home (Marguerat, 1999). The eldest child is educated with a view to becoming a future responsible family head and this education is very severe. Furthermore, child fosterage is frequent as, in some cases, fathers do not tolerate the presence of an older boy in the household, viewing him as a potential threat to their parental authority (Vandermesch, 1999). Some children will not put up with this situation, and decide to leave home in order to live their own life. 
Family violence and child neglect are therefore important factors, but three questions remain to be answered: firstly, that of the difference between girls and boys, secondly whether the violence is viewed as being fair or unfair, and finally the connection between family violence or neglect and poverty.

\subsection{Abuse and neglect and beyond}

Firstly, according to Aptekar and Ciano-Federof (1999), if neglect and abuse are the main triggers in the creation of street children, we would expect to see more street girls than street boys, because girls are generally subjected to more sexual abuse than boys. But this is not the case. The number of street boys is consistently higher, and this is thought to be because girls are subjected to tighter control. In Bangladesh and in Bombay (India) the small number of street girls is thought to be because they face less physical violence in the home than boys (Conticini and Hulme, 2007; Kombarakaran, 2004). It is also less easy for them to run away from home (Le Roux and Smith, 1998b; Sherman et al., 2005). Instead they are taught to tolerate poverty within the home, and to seek support from their relatives and other community members. It is less culturally acceptable for a girl to live on the street. Consequently they are more commonly used as domestic workers in order to free the time of adult women for wage earning. This contrasts markedly with boys, who are both expected and taught to earn money in the market and to be more independent (Aptekar and Ciano-Federof, 1999). A boy's duty is to work towards supporting the family, and this explains why they become independent at an early age.

Secondly, physical violence in the form of beatings is common in a number of cultures, with sub-Saharan Africa (Marguerat, 1999) and Bangladesh (Conticini and Hulme, 2007) being examples of where it is viewed as part of a child's education. Violence is present within the household, but also in schools and is readily evident within the community. It is expected that by such methods, children will learn to respect and obey their elders (Mbaye and Fall, 1996), and be made to take responsibility for their actions (Conticini and Hulme, 2007; Matchilda, 1999). Such "violence" is considered to be fair and just. When delivered in this way, violence as punishment is culturally accepted both by society and by the children themselves. Physical punishment is considered to have socialising properties, and even children themselves often assume that despite its use, their parents love them. It is cited as 'being for their own good', especially when they have done something wrong or something that is not allowed. Physical violence is also exerted to control children and how they spend their time. Thus parents can allocate the child's time in different ways without facing any opposition. In the same cultural setting, illegitimate or unfair violence is that which the child cannot justify. An example would be where a drunken father beats his child for no apparent reason. The repetition of a violent act can also make the distinction between fair and unfair violence unclear in the mind of the child, and punishment is no longer seen as having any educational or socializing value, and becomes simply violence. Lugalla and Mbwambo (1999) state that violence within the household cannot be considered to be a reliable category; as it relies entirely on children's point of view. However, according to Ballet et al. (2007) and Abdelgalil et al. (2004), the opinion of the parents is also insufficient on its own. Additionally Ballet (2006) states that the picture painted by parents and children to explain why the children have run away from home can be quite different. For example, even when some parents recognize that they have been violent towards their children, they blame this on the child's misbehavior.

Thirdly, according to Ballet et al. (2007) violence alone cannot often fully explain why children run away from home. Similarly, the poverty factor is insufficient, and both factors must be considered together with other contributing issues. In Mauritania for example, 
even where both parents work, children still run away. Ballet et al. (2007) distinguish between four categories of children of the street. The first is based on the poverty hypothesis only. Children run away from home to work, and become children of the street as a result. The second corresponds to the abuse and neglect hypothesis. These families are not always among the poorest, but the children have been maltreated. These two categories in fact constitute only a small fraction of children of the street. The bulk of street children belong to the two other categories. The third category is constituted by families where parents may not allocate enough time to childcare, because they have to work outside the home. If children from these households suffer parental neglect, this is always because the low income of parents does not allow them to pay someone to look after the children. Finally, the fourth category is that of families who send their children to work in the street, and even exert violent pressure on their children to bring back enough money. Here too a cumulative mechanism between poverty (these parents generally do not work themselves) and abuse is observed.

As can be seen, the phenomenon of living on the street is caused by a multiplicity of interacting factors including poverty, which may or may not be combined with violence and lack of parental care. Children who do not find their place in the household run away.

\section{Living conditions of children of the street: managing to survive and the street career}

The street is the place where children seek freedom as well as the security that they no longer have in their family home. Unfortunately the street, where they live and work, is prone to other forms of violence (Chalhub de Oliviera, 1997; Sherman et al., 2005), and the activities of children of the street are far from being without dangers and effects on health. In most of the cases, children of the street are organized to protect themselves. But if gangs in the street have a positive side, they also have a negative side. In fact there are different categories of gangs: social gangs, defense gangs and violence gangs (ASOARTE et al., 2002).

\subsection{Activities of children of the street and their organization}

Once children are on the street they have to work in order to survive. The work done by children appears to be very similar worldwide, and the differences reflect the economic development of the country concerned (Brink, 2001). Within the environment of the street, children compete to find the best opportunities for work, which means that they are often located in places where there is dense economic activity such as market places, taxi stands, railway stations and in city centres. In such places they can offer their services to passengers, shops, restaurants, and hotel owners. They work as food vendors and perform tasks such as car washing, rag picking, shoes shining and restaurant work. For instance, in Bombay, street children scavenge for recyclable scraps, as well as working at wedding parties (Patel, 1990; Kombarakaran, 2004).

Those who cannot find work, beg and steal to earn a living, and they acquire considerable understanding and coping skills to help them survive (Foley, 1983; Aptekar, 1989a; Kombarakaran, 2004). Some children buy goods cheaply for resale at a higher price, and although they do not earn very much in relation to the effort spent, this enables them to get by. Some however, are exploited by adults and where this is the case, they are sometimes not paid for their work (Lalor et al., 1999). In Bombay 70\% of children of the street earn from Rs 600 to 2000 ( $1 \$=$ Rs 48) a month, with older children earning more because their work is harder than that done by younger children. The money earned is spent on food consumption, drugs, clothes, and for sex (Kombarakaran, 2004; Rizzini and Butler, 2003). Some children of 
the street actually end up adopting a sort of "culture of consumerism" (Lugalla and Mbwambo, 1999).

Not all street children earn enough money to buy their food, and are reduced to eating leftovers from restaurants, bars and hotels. In Bombay, some street children live near Muslim shrines in order to get free food (Kombarakaran, 2004). Other children steal to survive, and although this usually only amounts to petty theft, they can also be taken on as drug couriers or work in prostitution. They work more than 40 hours a week (Rizzini and Lusk, 1995) and "live a day to day life" (Kombarakaran, 2004).

Sometimes children live near the places where they work. For instance, in Tanzania children of the street live on pavements near their working places (Lugalla and Mbwambo, 1999). Such proximity affords opportunities and gives them an advantage over other working children. Competition for acquiring better working places however, is more often regulated by violence. In order to preserve their advantage in a specific area of the city the older children of the street, adults and policemen, all exert physical violence against the younger children to force them to work in less lucrative areas (Lalor, 1999; Kombarakaran, 2004). This makes it particularly difficult for young children to survive on the street.

Nevertheless, street life is not without its rules, and activities are usually organized and regulated by gangs. For instance, Morelle (2004) describes the organization of activities among children of the street in Yaoundé, Cameroon. Car washing is organized according to age group. The groups consisting of older children strategically occupy the most lucrative geographical locations, whereas the younger age groups occupy less and less profitable locations as their age decreases. Children move on from one group to the next as they get older. They develop a strategy of a "street career" (Lucchini, 1993). Thus the activity of the children can depend closely on their membership of a social network, and more particularly of a group or gang (Campos et al., 1994).

\subsection{The positive side of gangs}

The notion of protection is essential for children of the street. They have to cope with different kinds of danger on the street. The violence is even greater than at home. They have to fight with other street children, adults and policemen in order to earn their livings. To face the violence of the street they need the support of other children, and so they form groups. The gangs provide them with the protection that they have lost by leaving home or never received from their parents. The gang is a substitute for parental protection, and is considered to be a family when the ties between the children are strong. Oliviera Ribeiro and Trench Ciampone (2001) find evidence in Porte Alegre, Brazil, that children neglected by the parents or who are victims of abuse, form a new family with other children of the street. The street family is organized like a real family, with a mother and father, uncles, aunts, brothers and sisters. All the members of the family have a specific role to play, and respect the rules of the family. However, these rules are not as constraining as they can be in a normal family.

Gangs usually protect children in three ways. First, they protect the children from other children of the street. Children regularly become victims of violence from other children of the street. They are often beaten, severely injured by stabbing, slashed by razor blades and suffer fractured skulls or other broken bones (Lalor et al., 1999). Beatings can also happen when older street children demand money from younger children. The longer a child spends on the street, the more he or she becomes absorbed into a street lifestyle (Le Roux, 1996), and gangs are regularly age based. For instance in the Democratic Republic of Congo, children of the street are known as Moineaux, Shege, Phaseurs, depending on their age group (Pirot, 2004). Children in gangs support each other when they are attacked, and younger children in 
particular, are less likely to have their earnings or goods stolen (Lalor et al., 1999; Kombarakaran, 2004).

Secondly, gangs protect children against police aggression and harassment, and sometimes against the population. In all developing countries, children of the street are subjected to assaults from the police. The reason for this is that majority public opinion considers children of the street to be delinquents who are a threat to society. In Colombia and Bolivia they are viewed as 'predators' (Rizzini and Lusk, 1995). This means that these children must be eliminated (Scalon et al., 1998), and in Brazil "death squads" are known to have killed children of the street who are blamed for rising crime rates and other delinquent behavior (Lalor, 1999). Children of the street are often arrested by the police, and put in jail where they may be beaten and/or otherwise abused, and where they are often humiliated by police officers. In Mauritania, children who are arrested are tied to the posts of the police station, and beaten with electric cable, a practice known as the "Jaguar" (Lefort, 1989). Brutality is supported by outmoded laws (Rizzini and Lusk, 1995). The police confiscate any money these children may possess, and forbid them to work on the street (Kombarakaran, 2004). Because of this, any person considered to be an ally of the police is thought of as 'the enemy' (Oliviera-Ribeiro and Trench-Ciampone, 2001).

Thirdly, gangs fulfil the affective needs of its members, and protect them in times of illness and pain. Gangs constitute a family, and like a family its role is to care for and love, and protect and emotionally support its members. The street is a stressful and depressing place (Le Roux and Smith, 1998c), and "family" members try to relieve each other's pain. When a child is ill, the "family" will take care of him, and provide him with medicine (Oliviera Ribeiro and Trench Ciampone, 2001), as well as sharing their money and food (Stephenson, 2001). The group prevents children from being completely marginalized and falling into depression, which usually leads to the use of drugs.

In addition to these three types of protection, in very rare cases gangs may also provide rules of behavior. For instance Stephenson (2001) describes gangs in Moscow that are regulated by codes of acceptable behavior. The group does not allow its members to earn money by begging, because "family" members are supposed to help each other by providing money. Stealing is also forbidden, as it gives the group a bad name. However, the social structure known as Arbat excludes young children who have insufficient "cultural capital", and those who have "undeveloped sociability". This system is mainly organized by children from the middle class.

\subsection{The negative side of gangs}

If gangs can have a positive side, they also have a negative side. This negative side is mainly related to the use of drugs, and the violence and abuse that occur within gangs.

The use of drugs is not automatic for all children of the street. Younger children for example are less likely to use drugs, but the likelihood increases with exposure to street life, and many of them do become addicted (Sherman et al., 2005). For instance in Brazil (Rizzini and Butler, 2003; Inciardi and Surratt, 1998), in India (Pagare et al., 1983), in Honduras (Wittig et al., 1997) and Pakistan (Sherman et al., 2005), almost all street children sniff glue, and it has been shown that using milder drugs can lead on to the use of more potent ones. Fortunately this is limited by the relatively high cost of hard drugs. In the streets of Rio de Janeiro and also in Lahore, marijuana is popular among street children, as it produces relaxation, which gives the children some relief from the stress of their daily life (Rizzini and Butler, 2003; Sherman et al., 2005). Some drugs can also suppress appetite, and this allows children occasional relief from hunger. Drug use is not entirely attributable to belonging to a 
gang, but the fact of being a member of a gang does increase the likelihood of taking drugs to fit in with the rest of the gang.

Belonging to a gang also involves accepting a hierarchy and submitting to the "elders". For instance, in Colombia, there are two groups of street children, one known as the gamines and the other as the chupagruesos (Aptekar, 1989b). The gamines group is composed of children who have been on the street for a long time, and enjoy the liberty the street can bring. The chupagruesos group is composed of more fragile children, who are not strong enough to support themselves or to face the difficulties of the street alone. Hence, they seek the support of other children who are more 'street-wise,' although to elicit this support the weaker children have to submit to an economic and hierarchical group structure. All the children are assigned some specific task to do such as, working, stealing or begging, and the group acts like a family with a head who coordinates the action of the members. But the price to be paid is a complete subordination, and often involves granting sexual favors in exchange for protection.

In the same vein, in Bombay younger boys exchange sexual favors for protection, food and movie tickets (Kombarakaran, 2004), and similar patterns are also seen in Ethiopia (Lalor et al., 1999), in South Africa (Swart-Kruger and Richter, 1997), in India (Ramakrisna et al., 2004) and in Lahore, Pakistan (Sherman et al., 2005).

\section{Conclusion}

Eradication of children of the street by violent methods cannot solve the problem, but it can exacerbate it by reinforcing the feelings of rejection and of alienation from society's rules experienced by such children. Institutional violence removes the trust children have in adults and adult society. Once this is lost, it is not surprising that these children show hostility, suspicion, low self-esteem and feelings of rage (Dubrow, 1992). Meanwhile, those who can avoid drug abuse are often able to develop considerable personal skills and selfesteem (Aptekar, 1994; Oliviera Ribeiro and Trench Ciampone, 2001; Horna Padron, 2007).

Violence against street children is not only a sign of State impotence, but of a larger failing within society to address broader inequalities. Any effective approach must therefore consider how best to deploy funding so that the initial effects can ultimately have more farreaching consequences.

Immediate difficulties, such as a lack of sanitation and poor nutrition, which cause poor physical and mental health as well as poor physical development (Saini and Shernavaz, 2001), can be readily addressed via the work of NGOs.

The role of NGOs has been mainly to provide education to children of the street in order to reduce their marginalization, and promote their integration into society (Brink, 2001). This has included specific re-integration and rehabilitation schemes aimed particularly at delinquents (Mufune, 2000; Scalon et al., 1998). In Bombay, children of the street have some recourse to NGO facilities for bathing, free or low cost food, recreation and informal education (Kombarakaran, 2004). NGOs also provide shelters during the monsoon season, and some medical care. From such beginnings NGOs are well placed to extend their role in two ways, firstly by providing more safe environments either for living or working, and secondly by providing education. It is only when these have been established that more fulfilling and life-enhancing activities, such as the provision of opportunities for sport and other recreation, can be embraced (Brink, 2001; see also Volpi, 2002 for a presentation of promising practices).

In parallel, NGOs have to address the causes of children's being permanently on the street. Where this is a matter of poverty rather than one of violence, government support should be sought to provide some family-based economic assistance with the goal of enabling 
children to stay at home. Where domestic violence is the cause, then alternative sheltered accommodation should be made available. It is reported that in Bombay, children who have been returned to a violent home under the control of NGOs have subsequently run away to live on the street again (Kombarakaran, 2004). Some schemes have been successful and are particularly encouraging, indicating that it is possible to rescue a fair number of these children of the street from their situation, and allow them to enjoy a better life. From this point of view, Biggeri and Anich (2009) note, on the basis of research done in Kampala, Uganda, that children of the street are quite capable of expressing an opinion about what needs to be done to improve their quality of life and to define the relevant priorities. Involving children of the street in devising programmes intended for them is also a good way of rehabilitating these children by changing the image they have of themselves, and that other people have of them (O’Kane, 2003).

\section{References}

Abdelgalil, S., Gurgel, R. G., Theobald, S. and Cuevas, L. E. (2004), Household and Family Characteristics of Street Children in Aracaju, Brazil, Archives of Disabled Child 89, pp. 817-820.

Aderinto, A. A. (2000), Social Correlates and Coping Measures of Street Children: A Comparative Study of Street and Non-Street Children in South-Western Nigeria, Child Abuse \& Neglect 24(9), pp. 1199-1213.

Alexandrescu, G. (1996), Programme Note: Street Children in Bucharest, Childhood, The Global Journal of Child Research 3(2), pp. 267-270.

Aptekar, L. (1988), Street Children of Colombia, Journal of Early Childhood 8(3), pp. 225-241.

Aptekar, L. (1989a), Characteristics of Street Children of Colombia, Child Abuse \& Neglect 13, pp. 427-437.

Aptekar, L. (1989b), Colombian Street Children: Gamines and Chuoagruesos, Adolescence 24(96), pp. 783-794.

Aptekar, L. (1994), Street Children in the Developing World: A Review of their Condition, Cross-Cultural Research 28(3), pp. 195-224.

Aptekar, L. and Abebe, B. (1997), Conflict in the Neighbourhood: Street Children and the Public Space, Childhood, The Global Journal of Child Research 4(4), pp. 477-490.

Aptekar, L. and Ciano-Federoff, L. M. (1999), Street Children in Nairobi: Gender Differences in Mental Health, New Direction for Child and Adolescent Development 85, pp. 35-46.

Aptekar, L. and Stocklin, D. (1996), Growing up in a Particularly Difficult Circumtances: A Cross-Cultural Perspective, In: J. Berry, P. R. Dasen and T. S. Saraswathi (eds), Handbook of Cross-Cultural Psychology ( $2^{\text {nd }}$ ed), Volume 2: Basic Processes and Development Psychology (pp 377-412), Boston: Ally and Bacon.

ASOARTE, AMM, GEAC and MAFUM (2002), Exploring Youth and Community Relations in Cali, Colombia, Environment and Urbanisation 14(2), pp. 149-156.

Ballet, J. (2006), Les enfants des rues en Mauritanie: Pauvreté monétaire ou pauvreté affective, In: Ballet J. and Hamzetta B. (eds), Formes sociales de la pauvreté en Mauritanie (pp.77-112), Paris: L’Harmattan.

Ballet, J., Bhukuth, A. and Radja, K. (2006), Travail des enfants, enfants des rues et approche par les capabilités. Liens méthodologiques et implications pour les politiques, Ethique et économique/Ethics and Economics 4(1), http://ethique-economique.net.

Ballet, J., Bhukuth, A. and Radja, K. (2007), Rethinking the Role of Economic Factor in the Street Child Phenomenon: The Case of Children of the Streets in Mauritania, mimeo UVSQ, C3ED, Unplished paper. 
Barker, G. and Knaul, F. (1991), Exploited Entrepreneurs: Street and Working Children in Developing Countries, New York: Chilhope-USA.

Bibas, I. (1998), Street Children in Egypt: from the Home to the Street to Inappropriate Corrective Institution, Environment and Urbanization 10(1), pp. 201-226.

Biggeri, M. and Anich, R. (2009), The Deprivation of Street children in Kampala. Can the Capability Approach and Participatory Methods Unlock a New Perspective in Research and Decision Making?. Mondes en Développement. 37(2), pp. 73-93.

Blanc, S. C. (1994), Urban Children and Distress, Luxembourg: Gordon and Breach Publishers.

Brink, B. (2001), Working with Street Children: Reintegration Through Education, Support for Learning 16(2), pp. 79-86.

Chalhub de Oliviera (1997), Homeless Children in Rio de Janeiro: Exploring the Meanings of Street Life, Child \& Youth Care Forum 26(3), pp. 163-174.

Campos, R., Raffaelli, M., Ude, U., Greco, M., Ruff, A., Rolf, J., Autunes, C. M., Halsey, N., and Greco, D. (1994), Social Networks and Daily Activities of Street Youth in Belo Horizonte, Brazil, Child Development 65, pp. 319-330.

CIDA - Canadian International Development Agency (2001), Action Plan on Child Protection: Promoting the Rights of the Children who Need Special Protection Measures, Canada, Montreal.

Consortium For Street Children (1998), Prevention of Street Migration: Resource Pack, London, U.K.: Consortium For Street Children.

Conticini, A. and Hulme, D. (2007), Escaping Violence, Seeking Freedom: Why Children in Bangladesh Migrate to the Street, Development and Change 38(2), pp. 201-227.

Cosgrove, J. G. (1990), Towards a Working Definition of Street Children, International Social Workers 33, pp. 185-192.

De Boeck, F. (1999), Domesticating Diamonds and Dollars: Identity, Expenditure and Sharing in South-Western Zaïre (1984-1997), In: B. Meyer and P. Geschiere (eds), Globalization and Identity. Dialectics of Flow and Closure (pp.177-209), Oxford: Blackwell.

Densley, M. K and Joss, D. M. (2000), Street Children: Causes and Consequences, and Innovative Treatment Approaches, Work 15, pp. 217-225.

Dubrow, N. (1992), The Mental Health of Street Children. In Reaching the Hard to Reach: Health Strategies for Serving Urban Young Women (pp. 17-18), New York: Childhope.

Ebigbo, P. O. (2003), Street Children: The Core of Child Abuse and Neglect in Nigeria, Children, Youth and Environments 13(1), spring, http://cye.colorado.edu.

Ennew, J. (1994), Street and Working Children - A Guide to Planning, London: Save the Children.

Ennew, J. (2000), Why the Convention is not about Street Children, In: D. Fotrell (ed.), Revisiting Children's Rights: 10 years of the UN Convention on the Rights of the Child (pp. 169-182), The Hague/Boston: Kluwer Law Int.

Ennew, J. (2003), Difficult Circumstances: Some Reflections on "Street Children” in Africa, Children, Youth and Environment 13(1), spring, http://cye.colorado.edu.

Felsman, J. K. (1984), Abandoned Children: A Reconsideration, Children Today 13, pp. 13-18.

Felsman, J. K. (1989), Risk and Resiliency in Childhood: The Lives of Street Children, In: T. F. Dugan and R. Coles (eds), The Child in Our Times: Studies in the Development of Resiliency (pp.56-80), New York: Brunner/Mazel.

Foley, M. (1983), Coping Strategies of Street Children, Journal of Offender Therapy and Comparative Criminology 27(1), pp. 5-20. 
Glauser, B. (1990), Street Children: Deconstruction a Construct, In: A. James and A. Prout (ed.), Constructing and Reconstructing Childhood: Contemporary Issues in the Sociological Study of Childhood (pp. 138-156), London: Falmer.

Gordon, D. S. N., Pantazis, C., Pemberton, S., and Townsend, P. (2003), Child Poverty in the Developing World, Bristol: The Policy Press.

Gurgel, R. Q., Da Fonseca, J. D. C., Neyra-Castaneda, D., Gill, G. V., and Cuevas, L. E. (2004), Capture-Recapture to Estimate the Number of Street Children in a City in Brazil, Archives of Disabled Child 89, pp. 222-224.

Hall, T. and Montgomerry, H. (2000), Home and Away: 'Childhood', 'Youth' and Young People, Anthropology Today 16(3), pp. 13-15.

Horna Padron, M. (2007), Development of Emotional Capabilities as a Strategy for Human Development among Marginalized Children, Paper presented at the Workshop on Children's Capabilities, HDCA Thematic Group on Children's Capabilities, Florence, Italy, 18-19 April.

Hecht, T. (1998), At Home in the Street: Street Children of Northeast Brazil, New York: Cambridge University Press.

Inciardi, J. A. and Surratt, H. C. (1998), Children in the Streets of Brazils: Drugs Use, Crime, Violence, and HIV Risks, Substance Use \& Misuse 33(7), pp. 1461-1480.

ILO (1996), Child Labour Surveys: Results of Methodological Experiments in Four Countries 1992-1993, Geneva: ILO.

Kombarakaran, F. A. (2004), Street Children in Bombay: Their Stresses and Strategies of Coping, Children and Youth Services Review 26, pp. 853-871.

Lalor, K. J. (1999), Street Children: A Comparative Perspective, Child Abuse \& Neglect 23(8), pp. 759-770.

Lalor, K., Taylor, M., Veale, A., Hussein Ali, A., and Elamin Bushra, M. (1999), Victimisation Amongst Street Children in Sudan and Ethopia: A Preliminary Analysis, Proceedings of UNICRI Conference, Rome, UNICEF.

Le Roux, J. (1996), Street Children in South Africa: Findings from Interviews on the Background of Street Children in Pretoria, South Africa, Adolescence 31(122), pp. 423-431.

Le Roux, J and Smith, C. S. (1998a), Public Perceptions of, and Reactions to, Street Children, Adolescence 33(132), Winter.

Le Roux, J and Smith, C. S. (1998b), Is the Street Child Phenomenon Synonymous with Deviant Behaviour, Adolescence 33(132), pp. 15-25.

Le Roux, J and Smith, C. S. (1998c), Causes and Charateristics of the Street Child Phenomenon: A Global Perspective, Adolescence 33(132), Winter.

Lucchini, R. (1993), Enfants de la rue: identité, sociabilité, drogue, Paris, Genève: Droz.

Lucchini, R. (1996), The street and its Image, Childhood 3(2), pp. 235-246.

Lugalla, J. L. P and Mbwambo, J. K (1999), Street Children and Street Life in Urban Tanzania: The Culture of Surviving and Its Implications for Children's Health, International Journal of Urban and Regional Research 33(2), pp. 329-344.

Lusk, M. W. (1992), Street Children of Rio de Janeiro, International Social Workers 35, pp. 293-305.

Marguerat, Y. (1986), Une Pathologie Sociale, Symptômes et Traitement: Les gamins de la Rue à Lomé. Communication aux Journées de Réflexion sur la Pédiatrie, Lomé, 46 Février.

Marguerat, Y. (1999), Les actions en faveur des enfants de la rue au Cameroun. Relation d'une visite, Cahier de Marjuvia 9, pp. 128-136.

Martins, R. A. (1996), Censo de crianças e adolescentes en situação de rua en São José de Rio Preto, Psicologia Reflexão et Critica 9(1), pp. 101-122. 
Mbaye, M. S. and Fall, A. S. (1996), Un Tissu Social qui se Délite, Un Système qui se Fragilise: Stratégie de Scolarisation et Travail des Enfants au Sénégal, In: B. Schlemmer (ed.), L'enfant Exploité: Oppression, Mise au Travail, Prolétarisation, Paris: Karthala Orstom.

Morelle, M. (2004), La rue des enfants, les enfants des rues. L'exemple de Yaoundé (Cameroun) et d'Antananarivo (Madagascar), Unpublished PhD dissertation, University of Paris I Panthéon Sorbonne.

Morelle, M. (2006), Une approche géographique du travail des enfants des rues. Quelles activités pour quels espaces? Yaoudé (Cameroun) et Antananarivo (Madagascar), Ethique et économique/Ethics and Economics 4(1), http://ethique-economique.net

Mufune, P. (2000), Street Youth in Southern Africa, International Social Science Journal 164, pp. 233-243.

Oliviera-Ribeiro, M. and Trench-Ciampone, M. H. (2001), Homeless Children: The Lives of a Group of Brazilian Street Children, Journal of Advanced Nursing 35(1), pp. 42-49.

O’Kane, C. (2003), Street and Working Children's Participation in programming their Right, Children, Youth and Environment 13(1), spring, http://cye.colorado.edu.

Olley, B. O. (2006), Social and Health Behaviors in Youth of the Streets of Ibadan, Nigeria, Child Abuse \& Neglect 30, pp. 271-282.

Orme, J. and Seipel, M. M. O. (2007), Survival Strategies of Street Children in Ghana, International Social Work 50(4), pp. 489-499.

Pagare, D., Meena, G. S., Singh, M. M. and Seha, R. (2004), Risk Factors of Substance Use among Street Children from Dehli, Indian Pediatrics 41, pp. 221-225.

Panter-Brick, C. (2000), Nobody's Children? A Reconsideration of Child Abandonment, In: C. Panter-Brick and M. T. Smith (ed.), Abandoned Children (pp. 1-26), Cambridge, U.K.: Cambridge University Press.

Panter-Brick, C. (2003), Street Children, Human Rights, and Public Health: A Critique and Future Directions, Children, Youth and Environments 13(1), pp. 147-171.

Patel, S. (1990), Street Children, Hotel Boys and Children of Pavement Dwellers and Construction Workers in Bombay - How They Meet their Daily Needs, Environment and Urbanization 2(2), pp. 9-26.

Peacock, R. (1994), Street Children, Africa Insight 24(2), pp. 138-143.

Pirot, B. (2004), Enfants des rues d'Afrique centrale. Douala et Kinshasa. De l'analyse à l'action, Paris, Karthala.

Raffaelli, M. (1999), Homeless and Working Street Youth in Latin America: A Development Review, Interamerican Journal of Psychology 33(2), pp. 7-28.

Raffaelli, M., Campos, R., Payne Merritt, A., Siqueira, E., Autunes, C. M., Parker, R., Greco, M., Greco, D., Helsey, N., and the street youth study group (1993), Sexual Practices and Attitudes of Street Youth in Belo Horizonte, Brazil, Social Science and Medecine 37, pp. 661-670.

Rizzini, I. and Lusk, M. W. (1995), Children in the Streets: Latin America's Lost Generation, Children and Youth Services Review 17(3), pp. 391-400.

Rizzini, I and Butler, U. M. (2003), Life Trajectories of Children and Adolescents Living on the Streets of Rio de Janeiro, Children, Youth and Environment 13(1), spring, http://cye.colorado.edu.

Saini, A and Vakil, S. (2002), Migration in India: Education and Outreach for Street Children, Childhood Education Winter 2001/2002.

Scalon, T. J., Tomkins, A., Lynch, M. A. and Scalon, F. (1998), Street Children in Latin America, British Medical Journal 316, pp. 1596-1600. 
Sherman, S. S., Plitt, S., Ul Hassan, S., Cheng, Y. and Zafar, S. T. (2005), Drug Use, Street Survival, and Risk Behaviors Among Street Children in Lahore, Pakistan, Journal of Urban Health 82(3), pp. iv113-iv124.

Stephenson, S. (2001), Street Children in Moscow: Using and Creating Social Capital, The Sociological Review 49(4), pp. 530-547.

Swart-Kruger, J. and Donald, D. (1996), Crianças das ruas de Africa do Sul, Psicologia Reflexão et Critica 9(1), pp. 59-82.

Swart-Kruger, J. and Richter, L. M. (1997), AIDS-Related Knowledge, Attitudes and Behaviour among South African Street Youth: Reflections on Power, Sexuality and the Autonomous Self, Social Science and Medecine 45(6), pp. 957-966.

Taçon, P. (1992), Marco and the Malevolent Monsters, unpublished paper for presentation to the Organisation of African Unity and its international partners.

UNICEF (1984), Latin America Seminar on Community Alternatives for Street Children, Brasilia, Brazil, November 12-15.

UNICEF (1999), The State of the World's Children, New York.

UNICEF (2000), Les enfants domestiques, UNICEF, Florence, Italy: Innocenti Digest.

UNICEF (2002), The State of the World's Children, UNICEF, Oxford University Press, Oxford.

Veale, A. (1996), An Empirical and Conceptual Analysis of Street Children in Sudan and Ethiopia, PhD dissertation, University College, Cork.

Veale, A. \& Donà, G. (2003), Street Children and Political Violence: A Socio-Demographic Analysis of Street Children in Rwanda, Child Abuse \& Neglect 27, pp. 253-269.

Volpi, E. (2002), Street Children: Promising Practices and Approaches, Working paper, World Bank Institute, Washington D.C.

Wernham, M (2001), An Outside Chance. Street Children and Juvenile Justice - an International Perspective, London: Consortium for Street Children.

Witter, S. (2002), The silent majority: Child poverty in Uganda, London: Save the Children UK.

Wittig, M. C. W., Wright, J. D., and Kaminsky, D. C. (1997), Subtance Use among Street Children in Honduras, Subtance Use \& Misuse 32(7-8), pp. 805-827.

Young, L. and Barett, Hazel (2001), Adapting Visual Methods: Action Research with Kampala Street Children, Area 33(2), pp. 141-152.

Young, L. (2004), Journeys to the street: the complex migration geographies of Ugandan street children, Geoforum 35(4), pp. 471-488. 